\title{
Ambiguous Expectations for Intersectoral Action for Health A Document Analysis of the Danish Case
}

\author{
Heering Holt, Ditte; Waldorff, Susanne Boch; Tjørnhøj-Thomsen, Tine; Rod, Morten Hulvej
}

Document Version

Accepted author manuscript

Published in:

Critical Public Health

DOI:

10.1080/09581596.2017.1288286

Publication date:

2018

License

Unspecified

Citation for published version (APA):

Heering Holt, D., Waldorff, S. B., Tjørnhøj-Thomsen, T., \& Rod, M. H. (2018). Ambiguous Expectations for Intersectoral Action for Health: A Document Analysis of the Danish Case. Critical Public Health, 28(1), 35-47. https://doi.org/10.1080/09581596.2017.1288286

Link to publication in CBS Research Portal

\section{General rights}

Copyright and moral rights for the publications made accessible in the public portal are retained by the authors and/or other copyright owners and it is a condition of accessing publications that users recognise and abide by the legal requirements associated with these rights.

Take down policy

If you believe that this document breaches copyright please contact us (research.lib@cbs.dk) providing details, and we will remove access to the work immediately and investigate your claim. 


\section{Ambiguous Expectations for Intersectoral Action for Health: A Document Analysis of the Danish Case}

\section{Ditte Heering Holt, Susanne Boch Waldorff, Tine Tjørnhøj-Thomsen, and Morten Hulvej Rod}

Journal article (Accepted version)

Cite: Heering Holt, D., Waldorff, S. B., Tjarnhøj-Thomsen, T., \& Rod, M. H. (2018). Ambiguous Expectations for Intersectoral Action for Health: A Document Analysis of the Danish Case. Critical Public Health, 281), 35-47. 001: 10.1080/09581596.2017.1288286

This is an Accepted Manuscript of an article published by Taylor \& Francis in Critical Public Health on 09

Feb 2017, available online: http://www.tandfonline.com/10.1080/09581596.2017.1288286

Uploaded to Research@CBS: January २०19 


\title{
RESEARCH ARTICLE
}

\section{Ambiguous expectations for intersectoral action for health: A document analysis of the Danish case}

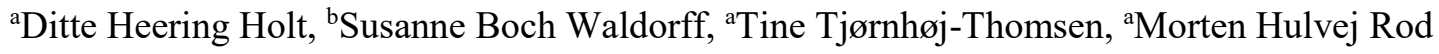 \\ ${ }^{a}$ Centre for Intervention Research in Health Promotion and Disease Prevention, National Institute of Public Health, \\ University of Southern Denmark, Copenhagen, Denmark; ${ }^{b}$ Center for Health Management, Department of \\ Organization, Copenhagen Business School, Copenhagen, Denmark
}

\begin{abstract}
Ideas about intersectoral action and policymaking for health (ISA) are prominent among public health professionals. They are often presented as effective ways to address root causes of poor health and health inequality, and as such the best way to promote population health. The implementation of such ideas has proven difficult though. In this paper we argue that neo-institutional theory can help us conceptualize implementation challenges by pointing to implicit expectations and contradictions associated with the ISA idea itself.

With Denmark as empirical case, we conducted a document analysis of recommendations for municipal ISA. The analysis shows how the recommendations provide a very abstract conceptualization of ISA that does not give much practical guidance for action. We show how ISA is discursively constructed with buzzword qualities as the natural way to organize health promotion, by being presented as a means to produce better quality services, more cost-effective operations, and ensure the future of the welfare state, while at the same time hardly changing much at all. By applying the lens of institutional logics we show how ISA, although being vaguely defined, offer ambiguous normative and symbolic repertoires for action. We discuss the implementation challenges associated with this advocacy rhetoric and suggest that the domination of the corporation logic may appear to reduce the political character of ISA and potentially conflict with the ideals of health as a matter of social justice and human rights.
\end{abstract}

Keywords: intersectoral action for health, municipal health promotion, governance

\section{Introduction}

Action across sectors is often presented as necessary to improve population health and ensure health equity (Freiler et al., 2013; Kickbusch, Williams \& Lawless, 2014; Ollila, Baum \& Peña 2013). This builds on concerns about the impact of social, physical and economic environments on health, often referred to as the social determinants of health (Commission of Social Determinants of Health [CSDH], 2008). That is, multiple factors impacting on health lie outside the health sector, such as employment, education, housing, transportation etc. As such, policies and services of non-health sectors have significant impact on public health (Baum, Ollila \& Peña, 2013). To accommodate this, the World Health Organization (WHO) and others have promoted concepts like intersectoral action for health (WHO, 1986, 2011), joined-upgovernment (Exworthy \& Hunter, 2011), and Health in All Policies (WHO, 2013). Overall, these concepts entail ideas about cross-sector collaboration and governance mechanisms, to help overcome the constraints of organizational and governmental silos and to ensure coordination and integration across sectors to achieve healthy public policies (Carey, Crammond \& Keast, 2014; McQueen, Wismar, Lin, Jones \& Davies, 2012). We use 'government-centered intersectoral action for health' (ISA) as a general term to refer to this trend. 
While ideas about ISA are generally popular, their implementation have been difficult (Hendriks et al., 2013; Ollila, 2011; Public Health Agency of Canada [PHAC], 2007). A growing body of scholarly literature addresses the lack of ISA implementation, typically by exploring barriers and facilitators as well as strategies for (better) implementation (Berkeley \& Springett, 2006; Freiler et al., 2013; Hendriks et al., 2013; Larsen, Rantala, Koudenburg \& Gulis, 2014; Rantala, Bortz \& Armada, 2014; Ollila, 2011). Governance structures, political leadership and capacity building are common themes, often with an instrumentalist ambition to advance the ability of public health professionals to engage other sectors in collaboration to promote health (Embrett \& Randall, 2014; McQueen et al., 2012). Much of the existing work resembles advocacy, and according to Chircop, Basset and Taylor (2015) the research on intersectoral collaboration remains superficial and lacks critical reflection about initiation and implementation.

Organizational neo-institutionalism provides a different perspective on implementation challenges, which is critical of an instrumentalist approach. By introducing the concepts of rationalized myth (Meyer \& Rowan, 1977) and institutional logics (Thornton, Ocasio \& Lounsbury, 2012), we explore how governmentcentered ISA is discursively constructed, by investigating the Danish case of municipal ISA in a document analysis. In line with Phillips, Lawrence and Hardy (2004) we find that language is fundamental to understand how definitions of social reality are constituted and shared, and we propose that document analysis may serve to investigate the inherent assumptions of the very idea of ISA. The aim is to analyze how the documents discursively produce ISA as a powerful solution while making various (conflicting) interpretations available for local actors.

The paper first introduces the method and theoretical framework. In the result section we show how ISA is constructed as common sense but entails complex and ambiguous expectations for action. We discuss how this may condition implementation, and suggest that the complexity and ambiguity created by multiple logics may help to explain some of the implementation challenges that are often disclosed in the scholarly literature about ISA. Finally, we question whether the dominance of corporation logic may potentially conflict with ideals of social justice and health as a human right.

\section{Empirical case and materials}

\section{The Danish case}

In Denmark, 'health across' is a popular ISA concept among public health professionals. It refers to all levels of cross-sector collaboration and policymaking, in particular municipal policymaking and interventions (Sandø, Finke, Aabel, Kristensen \& Ziebell, 2010). A reform in 2007 made municipalities responsible by law for general health promotion and prevention. This was done to aid the integration of health promotion within municipal welfare services such as schools, daycare, elderly care, social services, employment, and local planning (Hanak, Falk, Størup \& Bruun, 2007). The Danish political system functions to a great extent by decentralization (Bogason, 2013). The Health Act specifies that health promotion and prevention is a municipal responsibility, but not what it entails in any detail (Retsinformation, 2016). Instead, national agencies and other institutional actors use 'soft governance' (Brandsen, Boogers \& Tops, 2006) to guide local implementation. By developing guidelines and recommendations they contribute to shape local action (Rod \& Høybye, 2015). The high number of published guidelines makes the Danish case well suited for studying the expectations for ISA in a document analysis.

Our focus in this study is the expectations regarding the horizontal coordination and integration between government sectors at the municipal level. This contrasts much international literature that tends to focus attention on the national governmental level (Freiler et al., 2013; Ollila et al., 2013). However, De Leeuw and Clavier (2011) among others find that the local level is generally better than the national level in creating conditions for intersectoral engagement. This is not least true in Denmark, where municipalities are 
assigned the central role for doing health across, due to their proximity to local settings and the governmental structure with municipalities controlling many local services (Hanak et al., 2007).

\section{Data material}

Data consists of documents from two, national level, institutional actors: Local Government Denmark (LGD), an interest organization representing Danish municipalities; and the Danish Health Authority (DHA). These two organizations represent the main actors of national and local government. The selection criteria were defined as policy guidelines and recommendations for municipal health promotion and prevention, published 2004-2012. Data sources should give explicit recommendations about health across and/or address general organizing and planning concerns regarding municipal health promotion. The time period was chosen to accommodate documents relating to the reform, which was passed in 2004 and came into force in 2007.

A preliminary search was conducted in the DHA database, producing a list of 60 publications. The documents were sorted according to their relevance based on readings of abstracts and introductions. Technical reports, short leaflets, and near-duplicates were left out. Similarly, documents focusing on single risk factors were excluded, as they had little information on the organization of (intersectoral) efforts. A similar search for documents from LGD was not possible due to lack of a systematic database. A meeting was arranged with central employees at LGD to help identify relevant material in line with the established selection criteria. 10 documents were included in the final analysis with a total of 398 pages. They are referenced with numbers 1-10 throughout the analysis (see Appendix 1 for full list). Quotes have been translated by the first author with feedback provided by the co-authors. We note that the content of the analyzed documents varies across time and between organizations in terms of their emphasis on health across and the prominence given to different recommendations. However, we decided to delimit this question from the study, as the similarities across the documents were much greater than the differences, and the primary aim of the study was to identify more general characteristics of the health across discourse.

\section{Theoretical framework and analytical strategy}

Our study is informed by organizational neo-institutionalism, which is a theoretical field defined by a strong focus on the socializing effects on organizations by their institutional environment (Meyer \& Rowan, 1977). Neo-institutional theory has been applied in health care studies of topics such as change (Scott, Rueff, Mendel \& Caronna, 2000; Reay \& Hinings, 2005), health professionals (Dunn \& Jones, 2010; Goodrick \& Reay, 2010), prevention and health promotion (Waldorff, 2013); and health technologies (Currie \& Guah, 2007). We find neo-institutionalism particularly relevant to our study, as it helps us understand organizational action as a social construct, which is not only bound by rational strategic goals, but also by diverging values and social norms (Berg Johansen \& Waldorff, 2017). To analyze health across we draw on the concepts rationalized myth (Meyer \& Rowan, 1977) and institutional logics (Friedland \& Alford, 1991; Thornton et al., 2012). The concept of rationalized myth serves as an overall framework that guides the first part of the analysis. To further appreciate the complexity involved with implementation, the second part of the analysis applies institutional logics as a lens to help investigate the implicit and potentially conflicting values and practices entailed in the discourse on health across.

\section{Rationalized myth}

Rationalized myths are the conceptualization of popular organizational concepts as normative and symbolic constructs (Meyer \& Rowan, 1977). These constructs are "packaged" rhetorically as buzzwords: they excite and grab attention as powerful solutions to organizational challenges, due to their appearance as 
organizational tools - not their efficiency as instruments for change. They are adopted by organizations as symbols that demonstrate values like efficiency, rationality and progress, (Christensen, Lægreid, Roness \& Røvik, 2007; Meyer \& Rowan, 1977; Røvik, 2007). The concept of rationalized myth is based on the notion of institutionalization as processes where organizational concepts 'take on a rulelike status in social thought and action' (Meyer \& Rowan, 1977:341). It involves a social constructivist interpretation of human action, where organizational actors act in accordance with the social norms and perceptions of acceptable and legitimate action in an organizational field (Christensen et al., 2007; Meyer \& Rowan, 1977). This directs attention to how organizational concepts can gain popularity as common sense, and spread across organizational fields as circulating ideas regardless of their operational efficiency (Sahlin \& Wedlin, 2008). Examples of rationalized myths according to Meyer and Rowan (1977) are e.g. technical procedures, accounting, personnel selection and data processing, which have become taken-for-granted as means to accomplish organizational ends (Meyer \& Rowan, 1977). Later studies have focused on concepts such as Management By Objectives and Total Quality Management as rationalized myths. A main characteristic is that the management literature promoting these concepts spends more time defining the problems than outlining the proposed solutions (Røvik, 2002, 2007).

\section{Institutional logics}

Organizations strive to perform practices that are perceived as appropriate within their institutional environment. These practices - such as intersectoral action - carry different meanings or institutional logics. Institutional logics represent societal meaning structures that legitimize different kinds of organizational action (Thornton et al., 2012). Institutional logics are 'rules of action, interaction, and interpretation' (Thornton \& Ocasio, 1999:804) that are enacted and shaped in individual and organizational action (Berg Johansen \& Waldorff, 2017). We define institutional logics in line with Thornton and Ocasio (1999) as 'socially constructed, historical patterns of material practices, assumptions, values, beliefs, and rules by which individuals produce and reproduce their material subsistence, organize time and space, and provide meaning to their social reality' (Thornton \& Ocasio, 1999:804). The logics help shape action, because they structure individual and organizational attention and represent different expectations (Friedland \& Alford, 1991; Goodrick \& Reay, 2011). The co-existence of multiple logics helps explain institutional change as it leaves room for local interpretation (Goodrick \& Reay, 2011).

To analyze the presence and impact from institutional logics we are inspired by the typology developed by Thornton et al. (2012). The typology consists of ideal type logics such as state, market, profession and corporation, and it helps to operationalize the institutional logic concept for empirical analysis. The first author has accommodated the typology as shown in table 1.

Comparing the corporation logic and profession logic serves as an illustration of how logics represent meaning and practices associated with different societal spheres: The profession logic has the relational network between peers as its organizing principle. It refers to a code of ethics and peer surveillance as control mechanisms and entails professional control over the distribution of expertise. By contrast, the corporation logic has knowledge and expertise embedded in the hierarchy of the corporation. Here professionals are employees under the control of managers. The profession logic emphasizes quality of craft as rationale for action, whereas the corporation logic is concerned with managing efficient operations. Thus the typology specifies the rationales that shape individual and organizational attention and expectations within the sphere of influence of each logic (Thornton et al., 2012).

Table 1. Categories and characteristics of ideal type logics (inspired by Thornton et al., 2012).

\begin{tabular}{|l|l|l|l|l|}
\hline Categories & \multicolumn{4}{|l|}{ Institutional logics } \\
\hline & Corporation & Profession & State & Market \\
\hline
\end{tabular}




\begin{tabular}{|l|l|l|l|l|}
\hline $\begin{array}{l}\text { Organizing } \\
\text { principle }\end{array}$ & $\begin{array}{l}\text { Bureaucratic } \\
\text { hierarchy }\end{array}$ & Relational network & $\begin{array}{l}\text { Redistribution } \\
\text { mechanism }\end{array}$ & $\begin{array}{l}\text { Transaction } \\
\text { (invisible hand) }\end{array}$ \\
\hline $\begin{array}{l}\text { Rationale for } \\
\text { action }\end{array}$ & $\begin{array}{l}\text { Efficient } \\
\text { operation }\end{array}$ & High quality & $\begin{array}{l}\text { Increase community } \\
\text { and societal good }\end{array}$ & $\begin{array}{l}\text { Competitive advantage } \\
\text { Self-interest }\end{array}$ \\
\hline $\begin{array}{l}\text { Source of } \\
\text { authority }\end{array}$ & $\begin{array}{l}\text { Management } \\
\text { priorities }\end{array}$ & Expert judgement & $\begin{array}{l}\text { Government } \\
\text { regulation and } \\
\text { legislation }\end{array}$ & Supply/demand \\
\hline Guiding values & $\begin{array}{l}\text { Organizational } \\
\text { mission }\end{array}$ & Professional codex & $\begin{array}{l}\text { Equality before the } \\
\text { law } \\
\text { Democratic } \\
\text { participation }\end{array}$ & $\begin{array}{l}\text { Profit maximization } \\
\text { Commodification }\end{array}$ \\
\hline
\end{tabular}

\section{Analytical strategy}

The analytical strategy was informed by the theoretical framework, focusing on how health across is discursively represented as legitimate and desirable organizational action (Phillips et al., 2004). The documents were coded using Nvivo software. The qualitative coding focused on descriptions of organizational practices and processes, as well as language. Attention was paid to the use of metaphors, binaries, connotations and key concepts (Koch, 2011). The categories and characteristics from table 1 were used as a template to code institutional logics. Moreover, the documents were coded in an open thematic coding of: what constitutes health across; what are arguments to do health across; and how are key concepts, e.g. 'health' and 'citizen', constructed in the documents. The analysis was then to write up how health across was discursively produced, and contrast and compare across the logics to examine the multiple expectations associated with health across.

\section{Results}

First, we give an account of how health across is discursively constructed as common sense without much direction for action, displaying features of a rationalized myth. Second, we present a more detailed analysis of how the documents imply multiple institutional logics in the discursive representation of health across, hereby posing complex and potentially contradictory expectations for action.

\section{Popular idea without much direction for action}

In the documents, the concept health across is generally described with terms like 'creating coherence' (2, p. $7 ; 4$, p.19) and 'integrating health' $(6$, p.19; 9, p.8). The documents stress that health promotion is best considered an intersectoral task that needs to be integrated in other services and administrative departments across the municipality. Integration is described as 'thinking health' into daily operations $(1$, p.10; 7, p.34; 9 , p.8) and 'toning' existing operations with health promotion (5, p.6; 6, p.6). 'Toning' refers to the imagery of mixing paint colors to change them slightly. However, to 'think' and 'tone' does not signify much.

Nonetheless, these expressions are exemplary of the wording used to describe and define health across. Thus we find that health across is defined in vague terms with elusive and rather abstract terminology.

When looking at the actions described, health across involves two main activities: 1) creating 'healthy measures' ('Sunde rammer' can also be translated as healthy settings, environments or frameworks, depending on context), and 2) cross-sector health policy. 'Healthy measures' is a rather vague term that does not give much direction for action. When the documents specify it, they often refer to structural interventions: 
The effort to establish healthy measures for citizens is about "making the healthier choice the easier choice" by increasing the opportunities to make healthy choices or by regulating population behavior. In other words it is about establishing structural health promotion and prevention. $(7, \mathrm{p} .8)$

Thus, the exemplified healthy measures are usually about making healthy behaviors easier by means of structural interventions. Health policy, the other activity generally suggested, is also referred to as a healthy measure. It includes cross-sector health policy and health considerations in non-health policies. Policies are presented as important tools to ensure collaboration and coordination:

A municipal health policy with clear objectives ensures coordination, shared focus and secures long-term implementation. (4 p.19)

All analyzed documents recommend, or simply assume, the existence of a municipal health policy providing a mandate for health promotion across municipal sectors. Policies are assumed to ensure efficiency by making health a strategic priority.

Organizational structures are also mentioned in many documents as important, but few specific recommendations are given. E.g. when outlining different organizational models one document states:

There is not one specific organization model, which is superior to other models in terms of developing and implementing prevention and health promotion in municipalities across sectors (6, p.13). Regardless of organizational model, the answer [...] is often cross-sectoral collaboration $(6, \mathrm{p} .19)$

Finally, most documents mention local projects or suggest health interventions as examples of action. However, these examples mainly address what to focus on, e.g. promote physical activity in different sectors. Generally they do not describe how to do intersectoral efforts.

\section{Taken-for-granted as common sense}

Throughout the documents, health across is instilled with positive connotations. Phrases such as 'generating synergy' $(9$, p.73), 'utilizing potentials' $(7$, p.3) and 'exploiting opportunities' $(9$, p.35) invoke the notion that health across is a matter of harnessing benefits by making the most of existing resources. The documents present health across as a means to (better) reach the goals of the overall municipal organization. This is underlined by indications - implicit or explicit - that, exploiting this potential do not require many resources:

To integrate health promotion across policy sectors does not require new and resource-intensive interventions $(7, \mathrm{p} .8)$

The idea of integrating health promotion as part of already existing operations is fundamental in the documents. Together with the assumption that health across is a matter of using existing resources in a better way, the documents establishes a sense of ease and common sense associated with health across: Actions are not about introducing new activities, but simply to 'tone' and 'think' health into existing operations, hereby 'creating synergy' and 'utilizing potentials' with simple adjustments that may not imply much change at all. This way the documents construct health across as common sense by installing positive properties that are hard to oppose.

Reference to the 'cross-sectoral nature' of health promotion is another example of how health across is depicted as self-evident and common sense, the natural way to organize municipal health promotion: 
Many parts of the task of health promotion and prevention have a cross-sectorial nature $(6, p .7)$

Similarly, words such as 'necessity', 'obvious', 'invites itself' etc. depict health across as a necessary given. By being presented as obvious, necessary and natural, health across is constructed with buzzword qualities: it is an abstract idea not giving many practical guidelines for action, but presented as a powerful solution highly associated with positive properties. The taken-for-granted notion of necessity of cross-sector activity produces a sense of urgency. This helps build a rhetorically strong argument displaying features of a rationalized myth.

\section{Ambiguous expectations for action \\ Overall aim of health across}

Health across is generally legitimated by the major problems it is expected to tackle. The documents portray poor health and lifestyle diseases as great threats to society, both in relation to the general wellbeing of the population, as well as an economic threat to the state. Health across, as the so-called natural and efficient way to do health promotion, is presented as the solution:

Investing in municipal prevention is necessary if we want to avoid treating even higher numbers of chronically ill patients for decades to come $(5, \mathrm{p} .1)$

By reducing the demand for services, health across is suggested to counteract challenges regarding inequalities in health and increasing incidence of chronic illnesses. Challenges that strain the health care system and cause rising welfare costs overall. Health across is presented as an efficient organizational response against such economic pressures:

Since the existing budget does not hold prospects for increasing the local economic scope, ensuring citizens' continued access to core welfare services can pose a great challenge. Here health promotion can be part of the long-term solution. By promoting health $[\ldots]$ the demand for these services can be controlled. $(7, \mathrm{p} .6)$

When we apply our analytical lens, this argument entails multiple institutional logics: Emphasizing organizational solutions to tight economy entails corporation and market logics. That is, the argument is based on rationales of efficient organizational operations and economic incentives. Furthermore, the concern for providing welfare services is an expression of deep-rooted state logic that involves values about redistribution of resources and societal good. Thus the problematization that depicts health across as appropriate action combines multiple logics in the construction of health across as a desirable solution. Health across is presented as simultaneously improving organizational efficiency, controlling costs, and in effect ensuring the future of the welfare state. Hereby the rationalized myth of health across is instilled with very high hopes that are expressions of different logics.

\section{Expectations about results}

The construction of health across as a powerful and desirable solution is furthered by high expectations regarding the outcome; that health across will simultaneously improve the quality of services and efficiency of operations:

[A]health perspective can qualify the efforts of other services and thereby contribute to a more efficient use of municipal funds. $(7$, p.3) 
The objective should be that financing and incentives support a focus on quality and effectiveness $(9$, p.101)

While this expectation of improving both quality and efficiency would often be considered as contradictory, the documents generally advocate that health across ensures higher quality services by e.g. utilizing competences across sectors. In turn, this would improve the efficiency of existing resources by ensuring better effect. These expectations entail multiple logics; improving quality is a rationale for action of the profession logic, while efficient operations is an expression of corporation logic, and economic incentives relate to market logic. The notions of effect bring the logics together in constellation. 'Effect' is used to refer to both economic and operational efficiency and qualitative (health) effects. Often the concepts are linked by association in phrases such as 'quality and efficacy' (4, p.27) and 'quality and profitability' (10, p.20), hereby constructing health across as simultaneously economically sound and professionally desirable by displaying values from multiple logics.

Looking closer at the concept of quality, further ambiguity appears. Quality is to some extent associated with competences and professional proficiency in line with the ideal type profession logic:

Training is about developing [...] competences, so the quality of operations across departments is maintained and supported (10, p.23)

However, although professional knowledge and competences are mentioned as important, quality is predominantly associated with systematics, consistency and evidence as opposed to unfocused and heterogeneous efforts:

It is crucial for the quality of municipal services that work is carried out systematically, and prioritization is based on a well-documented foundation. This means that interventions must be based on the best possible knowledge and work will be monitored and evaluated to ensure quality and efficiency. (4, p.25)

Coherence and consistency are the main quality parameters, while monitoring and documentation are presented as ways to ensure quality and provide opportunities to learn from experience. This illustrates how the dominant notion of quality depicts a cooperative relationship between the profession and corporation logics: monitoring and documentation serve to produce professional knowledge, while also serving as management tools. The documents thus combine an emphasis on professional knowledge with demands of systematics, standardization and evaluation. This resonates with the corporation logic's demand for management information.

\section{Expectations about actors and organizing principles}

Politicians, professionals and managers alike are described as necessary actors to implement health across:

$[\mathrm{P}]$ oliticians, the administration and professionals must take responsibility $(1, \mathrm{p} .10)$

All three groups are depicted as actors whose advocacy, support and/or leadership are necessary. In particular strong management is emphasized:

[A]key element is to ensure that the responsibility for each intervention is clearly placed and managerial attention is guaranteed $(7, \mathrm{p} .38)$ 
Recommendations about strong management and (political) leadership constitute the main organizing principle throughout the documents. This involves expectations about management in charge of decisionmaking. Management is presented as directing action through strategies and action plans with clear goals:

First and foremost it requires that the municipality adopt shared strategies, goals and action plans $(1, \mathrm{p} .10)$

Health across is stressed to require clear goals and fixed targets, and monitoring and evaluation are thus important management tools to ensure implementation. The ideal is the rational organization that is directed by strategic goals and functions by clear role placements and classic bureaucratic hierarchy. Support from professional groups is recognized as important, but is not given much attention compared to management control and the confidence in policies with fixed targets, monitoring and evaluation to direct action. Hereby the corporation logic dominates as organizing principle.

We find that this call for strong management and leadership suggests health across to be a comprehensive and demanding effort that requires attention and determination:

[S] upport, ownership and actual demands for interdisciplinary cooperation on the entire organization from top-management and politicians ensure the necessary attention $(6, \mathrm{p} .22)$

This depiction of health across as a demanding effort is in contrast to the discursive construction of health across as being something fairly easy: as 'thinking health' into efforts they already do, as mentioned above. We find that this constitutes a paradox about what is required. Health across is depicted to require extensive management focus and capacity building while simultaneously being fairly easy, as the natural way to carry out operations that does not require much change at all. This paradox can be conceptualized as contradicting institutional logics. The importance of management, strong leadership, and clear placement of responsibility is a representation of the corporation logic. Expectations of integrating health promotion into daily operations as the quality of craft of professionals constitute profession logic. By presenting health across in this way, the documents use both logics to discursively legitimate action. Hereby, health across produces expectations that relate to different societal spheres and thus entail different rationales for action and different organizing principles. This way the documents produce a convincing argument, while simultaneously introduce contradicting expectations.

\section{Discussion}

We have examined how documents produce health across as a rationalized myth; a convincing and attractive organizational concept with buzzword qualities, taken-for-granted as the natural way to do health promotion but without providing much practical guidance. By applying the lens of institutional logics, we have shown how health across appeals to several different values. We argue that while these implicit expectations help to discursively construct health across as a legitimate solution to municipal challenges, and thus serve an advocacy purpose, they also pose complex and contradictory expectations for action. Based on this analysis we direct attention to two points for further discussion: 1) how we can conceptualize implementation challenges with neo-institutional theory, and 2) the political implications of the ISA rhetoric. First, we consider the generalizability of our findings.

\section{Generalizability of findings}

We suggest that buzzword qualities may apply more generally to ISA rhetoric, although some ISA initiatives are more specific regarding the tools than health across. ISA is generally assumed to produce synergies and 
help save costs (WHO, 2013; Baum, Lawless \& Williams, 2013). Greaves and Bialystok (2011) find that 'there is much agreement that [health in all policies] is "the right thing to do", "make sense", and is intuitively understood to save resources' (p. 3), while evaluations do not support claims about efficiency and cost-effectiveness (Ndumbe-Eyoh \& Moffatt, 2013; Shankardass, Solar, Murphy, Greaves \& O'Campo, 2012; Smith et al., 2009). In contrast, scholarly literature highlights the costs of intersectoral approaches and emphasizes the importance of critically assessing when, where and how ISA is required given the resource implications (Carey et al., 2014; Carey \& Crammond, 2015; Exworthy \& Hunter, 2011; PHAC, 2007). A similar concern is voiced by Chircop et al. (2015) who argue, with reference to Sharma and Kearins, that intersectoral collaboration as 'effective and efficient mechanism [...] is idealistic and perhaps overly simplistic' (p.186) but 'remains largely uncontested' (p.183). On this basis we suggest that ISA more generally displays features of a rationalized myth; as being more rhetoric than efficient governance techniques, packaged as symbols of efficient tools that appear as common sense (Meyer \& Rowan, 1977; Røvik, 2007).

\section{Implementation challenges}

Our analysis has shown that health across implies multiple institutional logics. The discourse on health across thus offers a repertoire of symbolic meaning for local actors to use in local translations of the idea, which may help us to further understand the organizational implications of implementing health across. Research shows that multiple logics can co-exist in different ways and may both constrain and enable action depending on the local context (Goodrick \& Reay, 2011; Waldorff, 2013; Waldorff, Reay \& Goodrick, 2013). The presence of multiple logics may therefore provide an opportunity for municipal actors to navigate and choose between different logics when appropriate and thereby enable action. But multiple logics may also pose constraints by placing multiple expectations on action and hereby adding up the number of requirements action must meet, or pose conflicting logics that restrict implementation (Waldorff et al., 2013).

Knowing that ISA implementation is difficult, we suggest that the ambiguous and potentially contradictory rationales for action hold the potential to constrain implementation. This is supported by Bryson, Crosby and Stone (2006) who note that the task of building legitimacy, leadership and trust only becomes more complex in intersectoral collaboration due to the likelihood that actors represent and enact competing institutional logics.

Indeed, Holt (2016) reports on an ethnographic study of health across, which shows that municipal actors struggle with meeting inconsistent demands that reflect the institutional logics analyzed above. The paper describes how actors are ambitious and dedicated to the task of realizing a new intersectoral health policy. However, tensions between inconsistent expectations limit implementation. The study demonstrates how the municipal actors reduce their implementation strategy to an abstract document that only consists of headlines, in order to sustain the inconsistencies and hereby the myth of health across. This way they maintain their high ambitions, but make no priorities for action and thus effectively decouple their intersectoral strategy from directing municipal action (Holt, 2016).

Another example of challenging implementation is a study of policy implementation in Varde municipality, Denmark, by Larsen and colleagues (2014). The study identifies a similar lack of prioritization regarding policy objectives and describes how an intersectoral group introduces intersectoral networks and funding, rather than specifying plans for action, when they develop an implementation strategy (Larsen et al., 2014).

The rationalized myth concept implies that the effects of implementation may not meet the initial expectations. According to organizational neo-institutionalism, this is not surprising because the implementation of a new (intersectoral) policy may be perceived as hampering organizational efficiency. 
One way of dealing with this is to adopt ISA at the political level as so-called 'window-dressing' (Christensen et al., 2007). That is, the rhetoric is incorporated in policies and language to gain legitimacy, but is decoupled from everyday operations to maintain efficiency (Meyer \& Rowan, 1977). This means that the concept is introduced rhetorically, but might not have much impact on sectoral practice. This way, the concept of decoupling seems to echo the calls for turning ISA rhetoric into action (Greaves \& Bialystok, 2011; Ollila, 2011). Neo-institutional theory consequently provides a perspective to contemplate lack of implementation of ISA that provides new insights to the field of public health. An interesting question for further research is how local actors resist or embrace the practices and symbols made available by multiple logics in different contexts.

\section{Political implications}

Beyond the question of implementation or lack thereof, the seeming dominance of the corporation logic (facilitated by the market and profession logics) may raise questions about the political implications of the advocacy rhetoric. In line with our social constructivist position, we find that language is not "innocent" (Phillips et al., 2004). The advocacy rhetoric promoting health across is not simply a tool to speak about the world "out there". Rather, it entails constructions of what the world is, or ought to be, which is political in the sense that it promotes some values and rationales for action as legitimate, while others are neglected.

By pointing to the dominance of the corporation logic, our analysis raises the question of whether efficiency is becoming an increasingly important value at the expense of e.g. social justice, human rights and equity. In a global perspective this is significant as ISA is usually promoted to address root causes of health inequalities, which relates to state logic rationales of societal good and redistribution.

While we find that the state logic is present in the discourse on health across, it functions primarily as a source of legitimacy in terms of defining the problem. Interestingly, this illustrates how institutionalized concepts change as they are translated into local settings (Sahlin \& Wedlin, 2008). However, we caution that the dominance of the corporation logic implies a faith in technical, bureaucratic solutions of fixed targets and effect evaluations, while the market logic favors values of cost-effectiveness. By drawing on these logics, the advocacy rhetoric promotes health across as a rather technical solution, an organizational "fix", to improve quality and efficiency of public services. However in doing so, the advocacy rhetoric indeed legitimizes these values of efficiency and cost-effectiveness as important and appropriate rationales for health promotion, rather than values like equity and social justice. So while the dominance of these logics may appear to reduce the political character of health across as merely a technical solution, it potentially conflicts with basic ideals of health as a matter of social justice and human rights (CSDH, 2008; WHO, 2013). We caution, that the long term consequence of using such rhetoric to promote health across, despite good intentions, may pose a risk to the ability to tackle health inequality as unfair and unjust (Marmot, 2010; CSDH; 2008).

\section{Limitations}

Organizational research has found that the presence of institutional logics impact the design and accomplishments of ideas, when they are implemented into different local contexts (Waldorff et al., 2013). The results of this paper are thus not directly generalizable, as ISA would be translated differently in different local settings. However, the paper demonstrates that organizational ideas about ISA, illustrated by the case of health across, are not straightforward, but constitute multiple, potentially conflicting, values and rationales for action. We believe this insight applies more generally to the advocacy literature promoting ISA, as discussed above. This poses an interesting question for further research. 
By choosing organizational neo-institutionalism as theoretical framework our focus is on the socially constructed rationales associated with health across. However, the study design does not permit us to observe how organizational actors engage and translate the social norms in their local practice. This topic is explored in Holt (2016) and would benefit from further consideration in future studies.

\section{Conclusion}

In this paper we show how policy guidelines discursively construct the ISA concept as an enticing commonsense idea. We provide evidence of the complexity of potentially contradictory values and rationales for action associated with the concept of ISA. By introducing the neo-institutional concepts of rationalized myth and institutional logics we contribute to broadening the discussion and reflections on the implications of ISA. We suggest that decoupling between organizational rhetoric and daily operations may help explain implementation challenges. Moreover, we caution that the advocacy rhetoric may hold implicit political implications.

\section{References}

Baum, F., Lawless, A., \& Williams, C. (2013). Health in All Policies from international ideas to local implementation: policies, systems, and organizations. In C. Clavier \& E. de Leeuw (Eds.), Health Promotion and the Policy Process (pp. 188-217). Oxford, United Kingdom: Oxford University Press.

Baum, F., Ollila, E., \& Peña, S. (2013). History of HiAP. In K. Leppo, E. Ollila, S. Peña, M. Wismar, \& S. Cook (Eds.), Health in All Policies. Seizing opportunities, implementing policies (pp. 25-42). Finland: Ministry of Social Affairs and Health, Finland.

Berg Johansen, C., \& Waldorff, S. B. (Forthcoming, 2017). What are Institutional Logics - and where is the perspective taking us? In G. Kruecken, C. Mazza, R. Meyer, \& P. Walgenbach (Eds.), New Themes in Institutional Analysis: Topics and Issues from European Research. Cheltenham, UK: Edward Elgar Publishing.

Berkeley, D., \& Springett, J. (2006). From rhetoric to reality: Barriers faced by Health For All initiatives. Social Science and Medicine, 63(1), 179-188.

Bogason, P. (2013). Forvaltning og stat [Public administration and the state] (Vol. 5). Copenhagen: Hans Reitzels Forlag.

Brandsen, T., Boogers, M., \& Tops, P. (2006). Soft Governance, Hard Consequences: The Ambiguous Status of Unofficial Guidelines. Public Administration Review, 66(4), 546-553.

Bryson, J. M., Crosby, B. C., \& Stone, M. M. (2006). The Design and Implementation of Cross-Sector Collaborations: Propositions from the Literature. Public Administration Review, 66, 44-55.

Carey, G., \& Crammond, B. (2015). What Works in Joined-Up Government? An Evidence Synthesis. International Journal of Public Administration, 38, 1020-1029. 
Carey, G., Crammond, B., \& Keast, R. (2014). Creating change in government to address the social determinants of health: how can efforts be improved? BMC Public Health, 14, 1087.

Chircop, A., Bassett, R., \& Taylor, E. (2015). Evidence on how to practice intersectoral collaboration for health equity: a scoping review. Critical Public Health, 25(2), 178-191.

Christensen, T., Lægreid, P., Roness, P. G., \& Rovik, K. A. (2007). Organization theory and the public sector: instrument, culture and myth. London: Routledge.

Commission of Social Determinants of Health (2008). Closing the gap in a generation: health equity through action on the social determinants of health. Geneva: World Health Organization.

Currie, W. L., \& Guah, M. W. (2007). Conflicting institutional logics: a national programme for IT in the organisational field of healthcare. Journal of Information Technology, 22(3), 235-247.

De Leeuw, E., \& Clavier, C. (2011). Healthy public in all policies. Health Promotion International, 26(suppl 2), ii237-ii244.

Dunn, M. B., \& Jones, C. (2010). Institutional Logics and Institutional Pluralism: The Contestation of Care and Science Logics in Medical Education, 1967-2005. Administrative Science Quarterly, 55(1), 114 149.

Embrett, M. G., \& Randall, G. E. (2014). Social determinants of health and health equity policy research: Exploring the use, misuse, and nonuse of policy analysis theory. Social Science and Medicine, 108C, 147-155.

Exworthy, M., \& Hunter, D. J. (2011). The Challenge of Joined-Up Government in Tackling Health Inequalities. International Journal of Public Administration, 34(4), 201-212.

Freiler, A., Muntaner, C., Shankardass, K., Mah, C. L., Molnar, A., Renahy, E., \& O'Campo, P. (2013). Glossary for the implementation of health in all policies (HiAP). Journal of Epidemiology and Community Health, 67(12), 1068-1072.

Friedland, R., \& Alford, R.R. (1991). Bringing society back in: Symbols, practices and institutional contradictions. In W. W. Powell \& P. J. DiMaggio (Eds.), The New Institutionalism in organizational analysis (pp. 232-263). Chicago: University of Chicago Press.

Goodrick, E., \& Reay, T. (2010). Florence Nightingale Endures: Legitimizing a New Professional Role Identity. Journal of Management Studies, 47(1), 55-84.

Goodrick, E., \& Reay, T. (2011). Constellations of Institutional Logics: Changes in the Professional Work of Pharmacists. Work and Occupations, 38(3), 372-416.

Greaves, L. J., \& Bialystok, L. R. (2011). Health in All Policies--all talk and little action? Canadian Journal of Public Health. 102(6), 407-409. 
Hanak, M. L., Falk, J., Størup, M., \& Bruun, J. J. (2007). Forebyggelse og sundhedsfremme i kommunen - en vejledning til Sundhedslovens $\$ 119$ stk. 1 og 2. [Prevention and Health Promotion in the municipality - a guide to the health care act $\$ 119$ stk. 1 and 2] Copenhagen: Sundhedsstyrelsen [Danish Health Authority].

Hendriks, A. M., Kremers, S. P. J., Gubbels, J. S., Raat, H., De Vries, N. K., \& Jansen, M. W. J. (2013). Towards health in all policies for childhood obesity prevention. Journal of Obesity, 2013. http://dx.doi.org/10.1155/2013/632540

Holt, D. H. (2016). Intersectoral policymaking for health? From policy to practice: a qualitative study of challenging implementation. (PhD dissertation), University of Southern Denmark, Copenhagen.

Kickbusch, I., Williams, C., \& Lawless, A. (2014). Making the most of open windows: Establishing health in all policies in south Australia. International Journal of Health Services, 44(1), 185-194.

Koch, L. (2011). Tekstanalyse [Text analysis]. In S. Vallgårda \& L. Koch (Eds.), Forskningsmetoder $i$ folkesundhedsvidenskab [Research methods in public health] (Vol. 4). Copenhagen: Munksgaard Danmark.

Larsen, M., Rantala, R., Koudenburg, O. A., \& Gulis, G. (2014). Intersectoral action for health: The experience of a Danish municipality. Scandinavian Journal of Public Health, 42(7), 649-657.

Marmot, M. (2010). Fair Society, Healthy Lives. The Marmot Review. UK: Strategic Review of Health Inequalities in England post-2010.

McQueen, D., Wismar M., Lin V., Jones, C. M., Davies M. (2012). Intersectoral Governance for Health in All Policies. Structures, actions and experiences. Copenhagen: World Health Organization on behalf of the European Observatory on Health Systems and Policies.

Meyer, J. W., \& Rowan, B. (1977). Institutionalized Organizations - Formal Structure as Myth and Ceremony. American Journal of Sociology, 83(2), 340-363.

Ndumbe-Eyoh, S., \& Moffatt, H. (2013). Intersectoral action for health equity: a rapid systematic review. BMC Public Health, 13, 1056.

Ollila, E. (2011). Health in all policies: from rhetoric to action. Scandinavian Journal of Public Health, 39(6), 11-18.

Ollila, E., Baum, F., \& Peña, S. (2013). Introduction to Health in All Policies and the analytical framework of the book. In K. Leppo, E. Ollila, S. Peña, M. Wismar, \& S. Cook (Eds.), Health in All Policies. Seizing opportunities, implementing policies (pp. 3-23). Finland: Ministry of Social Affairs and Health, Finland.

Phillips, N., Lawrence, T. B., \& Hardy, C. (2004). Discourse and Institutions. The Academy of Management Review, 29(4), 635-652.

Public Health Agency of Canada, (2007). Crossing Sectors-Experiences in Intersectoral Action, Public Policy and Health. Canada: Public Health Agency of Canada Calgary. 
Rantala, R., Bortz, M., \& Armada, F. (2014). Intersectoral action: local governments promoting health. Health Promotion International, 29(S1).

Reay, T., \& Hinings, C. R. (2005). The Recomposition of an Organizational Field: Health Care in Alberta. Organization Studies, 26(3), 351-384.

Retsinformation.dk, Bekendtgørelse af sundhedsloven, Kapitel 35, \$119 stk. 1 og 2 [The health act, chapter 35], https://www.retsinformation.dk/forms/r0710.aspx?id=152710\#Kap77 (last accessed, May 2016)

Rod, M. H., \& Høybye, M. T. (2015). A case of standardization? Implementing health promotion guidelines in Denmark. Health Promotion International, 31 (3), 692-703.

Røvik, K. A. (2002). The Secrets of the Winners: Management Ideas That Flow. In K. Sahlin-Andersson \& L. Engwall (Eds.), The Expansion of Management Knowledge - Carriers, Flows and Sources (pp. 113-144). Stanford, California: Stanford University Press.

Røvik, K. A. (2007). Trender og translasjoner: ideer som former det 21. århundrets organisasjon [Trends and translations: ideas that shape the 21st century organization]. Oslo: Universitetsforlaget

Sahlin, K., \& Wedlin, L. (2008). Circulating ideas: Imitation, translation and editing. In K. S. C. Oliver, R. Suddaby \& G. Royston (Eds.), Handbook of organizational institutionalism (pp. 218-242). London: Sage Publications.

Sandø, N., Finke, K., Aabel, M. K., Kristensen, T., \& Ziebell, B. (2010). Sundhed på tvoers [Health across]. Copenhagen: Sundhedsstyrelsen

Scott, W. R., Rueff, M., Mendel, P. J., \& Caronna, C. A. (2000). Institutional change and healthcare organizations: From professional dominance to managed care. Chicago: University of Chicago Press.

Shankardass, K., Solar, O., Murphy, K., Greaves, L., \& O'Campo, P. (2012). A scoping review of intersectoral action for health equity involving governments. International Journal of Public Health, 57(1), 25-33.

Smith, K., Bambra, C., Joyce, K., Perkins, N., Hunter, D., \& Blenkinsopp, E. (2009). Partners in health? A systematic review of the impact of organizational partnerships on public health outcomes in England between 1997 and 2008. Journal of Public Health, 31(2), 210-221.

Thornton, P. H., \& Ocasio, W. (1999). Institutional Logics and the Historical Contingency of Power in Organizations: Executive Succession in the Higher Education Publishing Industry, 1958-1990. American Journal of Sociology, 105(3), 801-843.

Thornton, P. H., Ocasio, W., \& Lounsbury, M. (2012). Defining the Interinstitutional System. In P. H. Thornton, W. Ocasio, \& M. Lounsbury (Eds.), The Institutional Logics Perspective (pp. 50-75). Oxford: Oxford University Press.

Waldorff, S. B. (2013). Accounting for organizational innovations: Mobilizing institutional logics in translation. Scandinavian Journal of Management, 29(3), 219-234. 
Waldorff, S. B., Reay, T., \& Goodrick, E. (2013). A tale of two countries: How different constellations of logics impact action. Institutional logics in action, Part A: Research in the Sociology of Organizations, 39A, 99-129.

WHO (1986). The Ottawa Charter for Health Promotion. Ottawa, Canada: World Health Organization.

WHO (2011). Intersectoral Action on Health A path for policy-makers to imlement effective and sustainable action on health. Kobe: The WHO Centre for Health Development, World Health Organization.

WHO (2013). The Helsinki Statement on Health in All Policies. Helsinki, Finland: World Health Organization. 


\section{Appendix 1}

\begin{tabular}{|l|l|l|l|l|}
\hline Nr. & Title & Pages & Publisher* & Year \\
\hline 1 & $\begin{array}{l}\text { Sundhed i Kommunen - nye opgaver og muligheder } \\
\text { "Health in the municipality - new tasks and possibilities" }\end{array}$ & 16 & DHA & 2005 \\
\hline 2 & $\begin{array}{l}\text { Kommunal sundhedspolitik - en KL-vejledning om indhold og } \\
\text { indsatser } \\
\text { "Municipal health policy - a LGD guide on content and } \\
\text { interventions" }\end{array}$ & 40 & LGD & 2006 \\
\hline 3 & $\begin{array}{l}\text { Idékatalog om borgerrettet forebyggelse } \\
\text { "Catalogue of ideas on population based prevention" }\end{array}$ & 34 & LGD & 2007 \\
\hline 4 & $\begin{array}{l}\text { Forebyggelse og sundhedsfremme i kommunen - en vejledning til } \\
\text { Sundhedslovens §119 stk. 1 og 2 } \\
\text { "Prevention and health promotion in the municipality - a guide to } \\
\text { \$119 article 1 and 2 of the Health Act" }\end{array}$ & 32 & DHA & 2007 \\
\hline 5 & $\begin{array}{l}\text { Udspil - kommunal forebyggelse der rykker } \\
\text { "Proposal - municipal prevention that works" }\end{array}$ & 10 & LGD & 2009 \\
\hline 6 & $\begin{array}{l}\text { Udfordringer i kommunernes organisering af sundhedsområdet } \\
\text { "Challenges in the municipal organization of health" }\end{array}$ & 26 & LGD & 2010 \\
\hline 7 & $\begin{array}{l}\text { Agenda sundhed på tværs } \\
\text { "Agenda health across" }\end{array}$ & 48 & DHA & 2010 \\
\hline 8 & $\begin{array}{l}\text { Social ulighed i sundhed - hvad kan kommunen gøre? } \\
\text { "Social inequalities in health - what can the municipality do?" }\end{array}$ & 56 & DHA & 2011 \\
\hline 9 & $\begin{array}{l}\text { Det nære sundhedsvæsen } \\
\text { "Local health care" }\end{array}$ & 108 & LGD & 2012 \\
\hline 10 & $\begin{array}{l}\text { Introduktion til Sundhedsstyrelsen forebyggelsespakker } \\
\text { "Introduction to the Danish Health Authority's prevention guidelines" }\end{array}$ & 28 & DHA & 2012 \\
\hline
\end{tabular}

* Danish Health Authority (DHA), Local Government Denmark (LGD)

Note: the English titles are translated by the first author. 